\title{
Problems in the Preservation and Study of Archaeological Metals in East Texas
}

Jay C. Blaine

Unknown

Follow this and additional works at: https://scholarworks.sfasu.edu/ita

Part of the American Material Culture Commons, Archaeological Anthropology Commons, Environmental Studies Commons, Other American Studies Commons, Other Arts and Humanities Commons, Other History of Art, Architecture, and Archaeology Commons, and the United States History Commons

Tell us how this article helped you.

This Article is brought to you for free and open access by the Center for Regional Heritage Research at SFA ScholarWorks. It has been accepted for inclusion in Index of Texas Archaeology: Open Access Gray Literature from the Lone Star State by an authorized editor of SFA ScholarWorks. For more information, please contact cdsscholarworks@sfasu.edu. 
Problems in the Preservation and Study of Archaeological Metals in East Texas

Creative Commons License

(C) $(1) \Theta$

This work is licensed under a Creative Commons Attribution-NonCommercial 4.0 International License 


\title{
Problems in the Preservation and Study of Archaeological Metals in Bast Texas
}

\author{
Jay C. Blaine
}

Dee Ann Story (1991) recently pointed out how little really is known about the archaeology of Texas Caddoan sites. Specifically, she notes how very few Caddoan sites have been systematically excavated and analyzed in Texas.

There has been some substantial effort in this direction recently as witnessed by the renewed investigations at the Sam Kaufman (Roitsch) site by the Texas Archeological Society and the Texas Historical Commission. However, it seems evident to some of us that while investigations of the prehistoric Caddoan archaeological data base has been less than adequate, our understanding of historic Caddoan groups remains even less satisfactory. In fact, archaeologically it is not yet possible to specifically and reliably identify many eighteenth century Indian sites in Eastern Texas as being affiliated with Caddoan peoples. Nor can we identify these Caddo from the many, more or less itinerant, candidates from among other tribes who may have paused and settled within known Caddoan tribal boundaries in historic times.

In dealing with these kinds of problems, it seems essential to first secure archaeological data from sites of limited time frames, and then to obtain information on other significant attributes, such as economic and status factors, for the occupations being examined. The imported artifacts of metal can form one of the potentially most useful categories for such data, although often they have been underutilized for this purpose in the past. While the archaeological metals are generally not easily dealt with on any level, this category of artifactual evidence need not continue to be slighted or their recovery generally considered to be of low priority.

As Story (1991) indicated, several Caddoan site artifact collections now in hand remain either largely unanalyzed, incompletely studied, or are in need of restudy. These collections and their data bases are at least now secured and not in significant jeopardy by further loss through natural or human processes. The same cannot be said for the archaeological metal components remaining buried in the historic Caddoan sites.

Here, in East Texas, I believe these metals are at significantly increasing risk from two fairly recent developments. One is the now widespread use of advanced metal detectors by persons who continue to disregard proper archaeological field techniques. Although they have become aware of our concerns and, in some cases, are at least exposed to some level of professional contact and advice, this behavior continues. 
The other damage is more indirect but apparently even more pervasive- the advent of significant episodes of acid rain. Without question the rate of decay for buried metals can be directly proportional to soil acidity. It is known that such metals could once reach a state of relative equilibrium with their immediate soil matrix. But now acid rains are, I have reason to believe, destroying any such balances, particularly where soil drainage is not optimal. In so far as such metals can be hoped to yield useful information, we are now losing this part of the data base. In my experience, artifacts of both iron and copper now being recovered in our area are generally in much poorer condition than those found some thirty years ago in the same sites. Although the surface attributes of these artifacts are the first to be lost, as would be expected, even the basic forms for the smaller items are sometimes unrecognizable now. As might also be expected, it will become increasingly difficult and expensive to preserve these artifacts for study, long-term curation, or exhibit.

One good example of the level of data being lost from archaeological metals comes from Illinois. At the eighteenth century village site of Kaskaskia some 11 knife blades were collected about 1901 . In most cases, even the makers names stamped into these blades were legible as French in origin. Similar blades recovered some 68 years later from this site are almost completly eaten away by rust. It is probable that the use of certain chemical fertilizers has accelerated such damage but since archaeological metals from wooden areas appear to be similarly affected, other causes must be involved.

In April 1988, Dr. George Crawford, a physics professor at Southern Methodist University, presented the results of a three year study concerning the acidity of rainfalls in North Dallas. Professor Crawford's experiments were far more elaborate than those conducted by the Texas Air Control Board and others, and his findings were startling. In 1985 , he found that 76 percent of rainfalls were more acidic than would be expected naturally, with over four percent of these rainfalls being extremely acidic. By 1987, 93 percent of the rainfalls were more acidic than normal and 12.5 percent were highly potent; that is, they were some 100 times more acidic than a natural and normal rainfall level. $\mathrm{He}$ was able to correlate these most acidic rains with south and east winds blowing across areas with coal-burning and lignite-fired power plants from as far away as Houston.

Now, not all sites or subareas within a given site provide equally destructive environments for their buried metals. For example, in North Central Texas and Eastern Texas metal artifacts positioned in a relatively sandy matrix with good drainage have suffered the least destruction. In cultivated fields, however, metal artifacts at and below the base of the plow zone, and particularly those in still deeper pits, are now found in increasingly much poorer condition. 
My purpose in this paper has been to remind us all that these particular areas of concern both continue to exist and to grow more critical. We are clearly losing a significant part of the data base by default, at least in the matter of unprofessional metal detector utilization. In that respect, perhaps we might consider initiating a vigorous survey program for locating suspected historic Caddoan sites. This effort, in utilizing the metal detector, could initially be directed toward mapping and piece plotting metal finds together with a limited sampling of those metals within detector range. If any nonprofessional aid in metal detection and sampling is considered, it should only be carried out under direct professional supervision and control. A similar effort was very productive at the Custer National Battlefield and has now provided concrete evidence for correcting and enlarging our perception of that historic and dramatic conflict.

Recently some of the magazines and books for relic collectors and metal detectorists have begun to include superficial advice on both cleaning and preserving their metallic finds. Most of these articles offer an interesting mixture of both relatively harmless, and/or bad, advice. Such catch-all kinds of information should not be accepted and followed uncritically by avocational archaeologists who would treat their excavated metals in a responsible manner. Publications by Hamilton (1976) and Plenderleith and Werner (1979) complement each other in offering the fullest range of options and procedures necessary for qualified metal conservation.

\section{References Cited}

Hamilton, D.L.

1976 Conservation of Metal Objects from Underwater Sites: A Study in Methods. Miscellaneous Papers No. 4, The Texas Memorial Museum, and Publication No. 1, The Texas Antiquities Committee. Austin.

Plenderleith, H.J. and A.E.A. Werner

1979 The Conservation of Antiquities and Works of Art. Revised edition, Oxford University Press, London.

Story, D.A.

1991 Some Comments on the Status of Caddoan Archeology. APR News \& Views 3 (No. 2):17-18. 